\title{
Profitability and Its Determinants in Turkish Manufacturing Industry: Evidence from a Dynamic Panel Model
}

\author{
Ozcan Isik ${ }^{1} \&$ Umit Firat Tasgin ${ }^{2}$ \\ ${ }^{1}$ School of Applied Sciences, Cumhuriyet University, Sivas, Turkey \\ ${ }^{2}$ Social Sciences Institute, Istanbul Aydin University, Istanbul, Turkey \\ Correspondence: Ozcan Isik, School of Applied Sciences, Cumhuriyet University, Sivas, Turkey. Tel: \\ 90-532-650-1298. E-mail: ozcan@live.com
}

Received: June 3, 2017

Accepted: June 15, 2017

Online Published: July 10, 2017

doi:10.5539/ijef.v9n8p66

URL: https://doi.org/10.5539/ijef.v9n8p66

\begin{abstract}
Our paper empirically analyses the factors that determine the profitability of 120 manufacturing firms listed in Borsa Istanbul Stock Exchange during the period 2005-2012. Estimation results from dynamic panel data model taking into account the endogeneity of variables indicate that lagged profitability, firm size, financial risk, R\&D costs, net working capital, and economic growth are the most important variables affecting firm profitability. More specifically, profitability is positively and significantly affected by past profitability, firm size in terms of total sales, net working capital, and economic growth. On the other hand, R\&D costs and financial risk have a dampening effect on the profitability.
\end{abstract}

Keywords: profitability, dynamic panel data, manufacturing industry, Borsa Istanbul, Turkey

\section{Introduction}

Analyzing the determinants of firm profitability in manufacturing industry is crucial with regard to the country's economy and industrialization (Voulgaris \& Lemonakis, 2014). At the macro-level, manufacturing industry is one of the strategically significant sectors making a major contribution to the development of Turkish economy. Being an important element of GDP, manufacturing industry is a driving force of economic growth (Bayar \& Tokpunar, 2014). At the micro-level, profitability is more likely to help firms to survive, grow, gain competitive power, and reduce external funding needs. In addition to this, the profitability, which is one of the most essential performance indicators for all the stakeholders, shows the success of the firm management by affecting firms' decisions concerning savings and investment (Al-Jafari \& Al Samman, 2015; Menicucci \& Paolucci, 2016; Akben-Selcuk, 2016). Accordingly, exploring of the drivers which influence the profitability of publicly traded manufacturing firms in Turkey is of great importance at both the macro-level and the micro-level.

Our study intends to re-investigate the associations between firm-specific variables and economic growth indicator and the profitability of Turkish manufacturing firms between 2005 and 2012. Our paper contributes to the literature regarding profitability determinants in the following manners. Firstly, although the association between profitability of manufacturing industry and its determinants is studied in a number of articles in the context of Turkish manufacturing industry, these articles generally use static panel data models and do not take into account the endogeneity issues between variables. In the present study, we account for endogeneity concerns by using dynamic panel data model. As well as we know, our study is the first to explore the linkage between economic growth and profitability of Turkish firms. According to the analysis results, while past ROA, firm size, net working capital, and economic growth are found to be statistically significant variables which positively affect the profitability, financial risk and the R\&D costs are found to have a significant and negative association with profitability. With respect to market risk and capital intensity, they are found to be insignificant in explaining the profitability.

The organization of the article is as follows: the next section presents a review of the literature on the determinants of profitability in both Turkey and other countries. The details of the data of manufacturing firms and research methodology are elaborated in the third section. While application results are reported and discussed in the fourth section, the last section concludes this article and gives some recommendations for further researches. 


\section{Literature Review}

In Turkey, Çakir and Küçükkaplan (2012) estimate the determinants of the profitability of 122 manufacturing firms quoted in Borsa İstanbul by using panel data analysis for the 2000-2009 period. In their study, they conclude that higher current ratio and higher leverage ratio are associated with lower profitability. On the other hand, stock turnover, asset turnover, and quick ratio have a positive impact on the profitability of quoted manufacturing firms.

Financial determinants of profitability of 78 manufacturing firms for the period 2000-2011 in Turkey are explored by Korkmaz and Karaca (2014) by using panel data analyses. Based on their findings, they conclude that tangible asset-to-long-term liabilities ratio, debt-to-total asset ratio, net sales-to-current asset ratio, and fixed asset-to-total asset ratio are the main financial ratios affecting ROA.

The factors affecting profitability of all Turkish publicly quoted firms during 2005-2014 is explored by Akben-Selcuk (2016). Based on the result of panel data analysis, she conclude that firms' ROA is negatively related to financial risk and R\&D costs and positively related to growth, level of liquidity, international sales and size.

On a sample of 15 listed industry firms in Turkey in the years 1997 and 2013, Kocaman, Altemur, and Aldemir (2016) try to identify the factors affecting the profitability by employing fixed effects panel data model. Econometric results show that while profitability is positively and significantly associated with net profit margin and receivables turnover, it is negatively and significantly correlated with financial leverage and asset tangibility.

In another study, using a sample of 136 Turkish manufacturing firms traded on the Borsa Istanbul Stock Exchange during 2005-2012, Doğan and Topal (2016) study the factors explaining the profitability. Estimation results obtained from pooled OLS regression analysis suggest that firm size is positively associated with ROA, whereas financial risk is negatively connected to ROA. However, the effect of firm age and liquidity level is trivial.

With the aim of assessing the profitability determinants of 11.682 firms operating in manufacturing and service sector during 1993-2001, Goddard, Tavakoli, and Wilson (2005) consider a panel data of 5 European countries (France, Italy, Spain, Belgium, and the UK). Their dynamic panel data results show that while gearing ratio and size of firm in terms of total assets have a negative impact on profitability measured by ROA, the variables like past profitability, liquidity level, and market share have a positive effect on profitability.

Using a sample of 175 listed firms in Chile during the period of 1995-2004, Martínez, Stöhr, and Quiroga (2007) examine the impact of some firm characteristics on firm profitability by using ordinary least square method. They conclude that while larger size significantly increases the profitability, the variables such as debt ratio and firm age are negatively and significantly associated with the profitability variable.

The factors explaining manufacturing firm profitability for Italy, Switzerland, and Sweden during the period 2003-2011 are studied by Hatem (2014). The empirical findings based on static panel estimation method indicate that profitability of manufacturing firms is positively and significantly associated with growth opportunities for all three countries. Only in the Swedish manufacturing industry, firm size affects profitability positively, whereas firm age influences profitability negatively.

Based on a sample of 22 SME firms listed in Indonesian Stock Exchange Market during the period from 2007 to 2012, Margaretha and Supartika (2015) try to analysis if the firm specific financial indicators affect profitability. While firm profitability is positively affected by industry affiliation and productivity, estimation results also imply that growth, the size of firm, and past profitability decrease profitability significantly. Meanwhile, firm age is found to be positive but insignificant in explaining profitability.

For Romania, using a sample of 46 firms listed on the Bucharest Stock Exchange for the period of 2009-2013, Vintilă and Nenu (2015) report that firm size in terms of employees and the ratio of sales to equity are positively and significantly correlated with ROA and ROE, whereas debt structure, asset tangibility, and growth in terms of sales are negatively and significantly associated with profitability measures.

Using static and dynamic panel data models, Vătavu (2014) explores how firm characteristics and economic conditions influence the profitability of 126 publicly listed firms for the 2003-2012 period in Romania. Regression results imply that lagged ROA, size, debt, liquidity, tangibility, the level of taxation are the most important factors in explaining ROA. On the other hand, there is no statistically significant relationship between firm risk and ROA. As for economic conditions, inflation rate and the latest economic crisis have a negative influence on ROA.

Niresh and Thirunavukkarasu (2014) analyze the association between firm size and profitability by focusing on 
publicly quoted manufacturing firms in Sri Lanka for time period 2008-2012. They employ return on assets and net profit ratio as indicator of profitability. As a result of their analysis, the authors conclude that the effect of firm-specific variables such as asset turnover and firm size indicators (i.e. log of total assets and log of total sales) on profitability measures is statistically insignificant.

In another paper from Sri Lanka, Pratheepan (2014) tries to investigate what determines profitability of 55 manufacturing firms quoted at the Colombo Stock Exchange during the period from 2003 to 2012. The results of the conducted panel data analysis show that while firm size significantly increase firm profitability measured by ROA, greater tangibility lowers ROA significantly. Besides, financial leverage and level of liquidity are not significantly associated with ROA.

Between the years 2008-2012, Sivathaasan, Tharanika, Sinthuja, and Hanitha (2013) investigate profitability determinants using a sample consisted of the 11 publicly traded manufacturing firms in Sri Lanka. Their results reveal that while profitability is significantly affected by capital ratio and non-debt tax shield, working capital, growth rate, and firm size do not have any significant influence on the profitability of sampled firms listed on Colombo Stock Exchange.

In Oman, Al-Jafari and Al Samman (2015) examine the profitability determinants of 17 industrial firms listed on Muscat securities market for the 2006-2013 period. The results obtained from regression analysis suggest that while profit margin and ROA are positively and significantly influenced by size, growth, and working capital, financial leverage affects each of profitability indicators negatively and significantly. However, tangibility has also a significant and positive influence on firms' profit margin.

In Pakistan, Abbas, Bashir, Manzoor, and Akram (2013) investigate the determinants of financial performance of 411 listed textile firms by using fixed effect model during the period 2005-2010. The results obtained from their regression equation indicate that financial performance measured by ROA as EBIT/Total assets is significantly affected by short term financial leverage, tax, non-debt tax shield, firm size, and risk.

Employing data on 30.764 private firms in the EU-15 area, Pattitoni, Petracci, and Spisni (2014) examine the profitability determinants during 2004-2011. The authors use both static and dynamic panel data models to estimate the impact of selected firm-level and macro-level variables on firm profitability measured by ROA. Estimation results from static and dynamic panel data analysis imply that while inflation rate, debt ratio, and firms size have a negative impact on profitability of private firms, net working capital-to-total assets ratio, growth rate of sales, opportunity cost of capital, majority shareholder, economic growth, and the annual return of market indices have a positive influence on ROA ratio. Besides, based on the analysis findings from their non-linear models, they conclude that there are nonlinear influences in terms of firm size, sales growth and debt ratio.

\section{Data and Methodology}

\subsection{Sample}

In our study a balanced panel data is constructed for the selected publicly quoted manufacturing firms that operate in Turkey for the time-period 2005-2012 by employing both firm-specific and macroeconomic data. The firm-specific data are obtained from FINNET database. This corporate database comprises information about all Turkish listed firms. Besides, macroeconomic level data is obtained from the website of Central Bank of the Republic of Turkey. Definition of variables used in our study, their expected signs, and distribution of firms operating in manufacturing industry by sectors are presented in Tables 1 and 2 respectively.

Table 1. Definition of variables used in this study

\begin{tabular}{|c|c|c|c|}
\hline Variables & Symbol & Description & Expected Sign \\
\hline \multicolumn{4}{|c|}{ Panel A: Dependent variable } \\
\hline Profitability & ROA & Net income over total assets & \\
\hline \multicolumn{4}{|c|}{ Panel B: Independent variables } \\
\hline Past profitability & $\mathrm{ROA}_{\mathrm{it}-1}$ & The one year lagged net income over total assets & Positive \\
\hline Firm size & Ln(Sales) & The natural logarithm of the firm's total sales & Ambiguous \\
\hline Capital intensity & CAPIN & total assets over sales & Positive \\
\hline Liquidity & NWC & Net working capital over total assets. & Ambiguous \\
\hline Financial risk & FINRISK & Total debt over total assets & Negative \\
\hline $\mathrm{R} \& \mathrm{D}$ costs & $\mathrm{R} \& \mathrm{D}$ & $R \& D$ costs over total revenues & Positive \\
\hline Market risk & BETA & $\begin{array}{l}\text { Estimate from market model in which monthly stock returns of the firm over } \\
\text { the past one year are regressed on XU100 index monthly returns }\end{array}$ & Positive \\
\hline Economic growth & GDP & Annual real GDP growth rate & Positive \\
\hline
\end{tabular}


Table 2. Distribution of firms operating in manufacturing industry by sectors

\begin{tabular}{ll}
\hline Sector & Number of firm \\
\hline Food, Beverages and Tobacco & 14 \\
Textile, Apparel \& Leather & 18 \\
Forest Products and Furniture & 1 \\
Paper and Paper Products, Printing \& Publishing & 11 \\
Chemical, Petroleum, Rubber and Plastic Products & 18 \\
Stone and Soil Based Industry & 24 \\
Main Metal Industry & 11 \\
Metal Goods, Machinery and Equipment Construction & 20 \\
Other Manufacturing Industry & 3 \\
Total & 3 \\
\hline
\end{tabular}

\subsection{Descriptive Statistics}

The summary of descriptive statistics of profitability, firm characteristics, and economic growth are given in Table 3. Our measure of profitability, ROA, has a mean of 0.0436 , a median of 0.0389 , and a standard deviation of 0.0859 . The ROA value of manufacturing firms varies over time in a range of -.1880 to .3505 . This means large variability in profitability of manufacturing firms. Additionally the outliers of ROA variable are determined employing the procedure of interquartile range (i.e. "iqr") of the STATA software and removed from our sample. Therefore, we try to prevent our results from being affected by ROA's extreme outliers.

Table 3. Descriptive statistics of regressors

\begin{tabular}{ccccccccc}
\hline Variable & ROA & Ln(sales) & FINRISK & CAPIN & BETA & NWC & R\&D & GDP \\
\hline Mean & .0436 & 5.2843 & .4127 & 1.9624 & .8336283 & .2081 & .0070 & .0448 \\
Median & .0389 & 5.1761 & .3960 & 1.1552 & .8321385 & .1980 & 0 & .0578 \\
SD & .0859 & 1.7251 & .2112 & 5.3220 & .27298 & .1895 & .0389 & .0459 \\
Min & -.1880 & -.5621 & .0064 & .1000 & -.57237 & -.4243 & 0 & -.0483 \\
Max & .3505 & 10.7586 & 1.3495 & 96.1753 & 1.56614 & .8451 & .6327 & .0916 \\
Obs. & 958 & 976 & 976 & 976 & 960 & 976 & 976 & 976 \\
\hline
\end{tabular}

Note. All variables are defined in Table 1.

\subsection{Pairwise Correlations}

The correlation matrix of the variables employed in Eq. (1) as well as analysis of variance inflation factors (VIFs) is reported in Table 4. The variable ROA is positively correlated with lagged ROA, $\operatorname{Ln}(\operatorname{sales}), \mathrm{NWC}, \mathrm{R} \& \mathrm{D}$, and GDP except for FINRISK, CAPIN, and BETA during the sampling period. The largest correlation coefficient between the variables is .62, and the VIF statistics of the variables are under the value of 5 . The results obtained from correlation matrix as well as VIFs analysis indicate that the results of our regression analysis are not driven by multicollinearity issue. Importantly, the fact that the correlation coefficient between lagged ROA value and the current value of ROA is .62 supports that our profitability equation should be estimated through dynamic panel data model.

Table 4. Correlation matrix

\begin{tabular}{|c|c|c|c|c|c|c|c|c|c|c|}
\hline & ROA & $\mathrm{ROA}_{\mathrm{it}-1}$ & Ln(sales) & FINRISK & CAPIN & BETA & NWC & $R \& D$ & GDP & VIFs \\
\hline ROA & 1 & & & & & & & & & \\
\hline $\mathrm{ROA}_{\mathrm{it}-1}$ & $.62 *$ & 1 & & & & & & & & 1.49 \\
\hline Ln(sales) & $.36^{*}$ & $.34 *$ & 1 & & & & & & & 1.37 \\
\hline FINRISK & $-.36^{*}$ & $-.35^{*}$ & $.17 *$ & 1 & & & & & & 4.15 \\
\hline CAPIN & $-.12 *$ & $-.13^{*}$ & $-.35^{*}$ & $-.14 *$ & 1 & & & & & 3.83 \\
\hline BETA & -.05 & $-.08 * *$ & $.16^{*}$ & $.10^{*}$ & .03 & 1 & & & & 1.07 \\
\hline NWC & $.40 *$ & $.37 *$ & -.05 & $-.54 *$ & -.5 & -.06 & 1 & & & 4.98 \\
\hline$R \& D$ & .02 & .01 & $.22 *$ & $.08^{* *}$ & -.02 & $.16^{*}$ & .02 & 1 & & 1.09 \\
\hline GDP & $.10 *$ & -.05 & .01 & -.03 & -.03 & -.05 & .05 & -.04 & 1 & 1.01 \\
\hline
\end{tabular}

Note. $*$ Level of significance for coefficients in correlation matrix are ***0.01 and $* * 0.05$. All variables are defined in Table 1. 


\subsection{Methodology}

We specify the following equation which is similar to that of Pattitoni et al. (2014) to investigate the influence of firm specific and economic growth on the profitability of firm:

$$
\begin{aligned}
& \mathrm{ROA}_{\text {it }}=\alpha+\gamma \mathrm{ROA}_{\mathrm{it}-1}+\beta_{1} \operatorname{Ln}(\text { sales })_{\mathrm{it}}+\beta_{2} \text { FINRISK }_{\mathrm{it}}+\beta_{3} \text { CAPIN }_{\mathrm{it}}+\beta_{4} \mathrm{BETA}_{\mathrm{it}}
\end{aligned}
$$

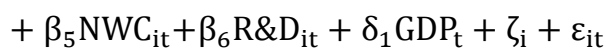

In this specification $\mathrm{ROA}_{\text {it }}$, the dependent variable, is measured by return on assets and denotes the profitability of firm $\mathrm{i}$ at time $\mathrm{t} ; \alpha$ is the constant term; $\mathrm{ROA}_{\mathrm{it}-1}$ is the profitability of firm $\mathrm{i}$ at time $\mathrm{t}-1 ; \zeta_{\mathrm{i}}$ is the unobserved firm-specific effect and $\varepsilon_{i t}$ is an error term. All other variables specified in the above specification are defined in Table 1. The possible relationships between firm-specific and economic growth and the profitability variable could be explained as follows:

Previous studies (e.g. Goddard et al., 2005; Isik \& Soykan, 2013; Pattitoni et al., 2014; Nunes \& Serrasqueiro, 2015; Vătavu, 2014; Cavaco, Challe, Crifo, Rebérioux, \& Roudaut, 2016; among others) on the relationship between ROA and $\mathrm{ROA}_{\mathrm{it}-1}$ show that profitability in the prior period has important influence on the current one according to the persistence of profit hypothesis developed by Mueller $(1977,1986)$. On one side, the fact that the coefficient of $\mathrm{ROA}_{\mathrm{it}-1}$ is found to be a low value means that manufacturing industry is highly competitive. On the other side, a high value for this coefficient means existence of the abnormal profits (i.e. insufficient competition). As a result, a value of $\mathrm{ROA}_{\mathrm{it}-1}$ between 0 and 1 supports the idea which profits persist.

Profitability is expected to increase as firm's size increases in view of the economies of scale hypothesis but agency problems between firm managers and shareholders of the firm cause the profitability to decrease, suggesting that a larger firm size is likely to be associated with lower profitability (Voulgaris \& Lemonakis, 2014; Pattitoni et al., 2014; Hatem, 2014).

Capital intensity of a firm is considered to be an important firm-specific determinant of profitability and it is measured by total assets-to-sales ratio. As discussed in Lee (2009), the effect of capital intensity on firm profitability is expected to be positive because this ratio reflects firm's market power.

Liquidity, as measured by net working capital-to-total assets ratio, is included in our model to assess the relationship between the level of solvency of the firm and the profitability. On one side, an adequate level of liquidity could help firms to expand their operations, pay their debts on time and take advantage of long-term profitable investment opportunities (Goddard et al., 2005). On the other side, According to the finance theory, having excessive liquidity not only reduces the risk of liquidity, but is also detrimental to firm's profitability (Myers \& Rajan, 1998; Çakır \& Küçükkaplan, 2012; Voulgaris \& Lemonakis, 2014). Therefore, the sign of coefficient of this ratio may be positive or negative.

Financial risk, which is measured by total debt-to-total assets ratio, represents the decisions regarding debt structure of the firm in our regression model. A negative connection could be expected between the financial risk and the profitability. Firms with higher debt ratio may experience cash shortages due to their periodic debt payments, which may cause them to miss out on lucrative investment opportunities (Pervan \& Mlikota, 2013; Wu, 2013; Pattitoni et al., 2014).

The influence of the R\&D costs-to-total revenues ratio on the profitability of firm is predicted to have a positive. While the production costs of firms with high level of R\&D intensity may be reduced, their productivity levels and competitive advantage are more likely to increase. Thus, the increase in the sales volume of the firms or the decrease of the costs leads to better profitability (Işık, Engeloğlu, \& Kılınç, 2016; Kafouros, 2005; Nunes \& Serrasqueiro, 2015; Akben-Selcuk, 2016).

Unlike most empirical studies (e.g. Pervan \& Mlikota, 2013; Miralles-Marcelo, del Mar Miralles-Quirós, \& Lisboa, 2014; Poutziouris, Savva, \& Hadjielias, 2015; Nunes \& Serrasqueiro, 2015; Cavaco et al., 2016; Zhou, He, \& Wang, 2017; among others), In this study, we chose market risk, which is popularly known as the systematic risk or beta, as a measure of risk because shareholders fundamentally worry about the risk that cannot be mitigated through the diversification strategy. Based on the risk premium hypothesis, shareholders are expected to earn a higher return in exchange for taking more risk i.e. a higher return is highly likely to be associated with higher risk.

In our regression model, we include economic growth variable represented by GDP to control the effect of macroeconomic conditions. An improvement in economic conditions is more likely to affect the aggregated demand and supply and thus profitability of the firm (Lee, 2009; Pattitoni et al., 2014; Voulgaris \& Lemonakis, 2014). We anticipate a positive coefficient for economic growth. 


\section{Regression Results}

The coefficient estimates for regression model specified in Eq. (1) where the dependent variable is return on assets (ROA) are reported in Table 5. Since the $\mathrm{ROA}_{\mathrm{it}-1}$ is likely to be correlated with $\zeta_{i}$ by construction, estimating our regression model by standard estimators such as pooled OLS (POLS) or fixed effects (FE) leads to biased and inconsistent results (Nickell, 1981; Bond, 2002; Schultz et al., 2010; Wintoki et al., 2012). Therefore, we estimate our regression model specified in Eq. (1) by employing system GMM (SGMM) estimator recommended by Arellano and Bover (1995) and Blundell and Bond (1998) because POLS and FE (within-group) methods cannot cope with the endogeneity of the $\mathrm{ROA}_{\mathrm{it}-1}$ and other possible endogeneity problems such as simultaneity and dynamic endogeneity (Greene, 2003; Schultz et al., 2010; Wintoki et al., 2012; Baltagi, 2014). The consistency of the SGMM estimator, our econometric methodology, depends both on the validity of our instrumental variables and on the serial correlation of the error terms. Thus, the validity of chosen instruments is tested by Hansen $J$-statistic (Ho is that the chosen instruments are valid) and the absence of first and second-order serial correlation in the error terms in our model is checked by the two statistics i.e. AR1 and AR2 (Ho is that there is no auto-correlation in first-differenced errors). However, we have to take into account the second-order autocorrelation AR2 in the equation in differences to test the absence of the first-order autocorrelation AR1 in the equation in levels (Arellano \& Bond, 1991). According to the diagnostic tests reported in Table 5, Hansen J-statistic implies that instrumental variables used in our dynamic model are valid and the AR2 test statistic shows no second-order autocorrelation in our regression model. Moreover, it is important for us to report the instrument counts used in the analysis when using SGMM estimator. As emphasized by Roodman (2009), the number of instrumental variables should not exceed the number of firms. This condition is also met by our regression specification. Finally, the POLS estimation of the coefficient of the $\mathrm{ROA}_{\mathrm{it}-1}$ in a dynamic panel regression specification is biased upwards by virtue of the fact that the POLS estimator does not consider the unobserved firm-specific effect, whereas the FE estimation takes into account the unobserved panel-level effects but causes an estimation of $\mathrm{ROA}_{\mathrm{it}-1}$ to be seriously downward biased because of short panel bias (Bond, 2002). Therefore, the estimated coefficient of $\mathrm{ROA}_{\mathrm{it}-1}$ from FE and POLS is highly likely to be an approximate lower and upper bounds for a consistent SGMM estimate of the coefficient for ROA $A_{i t-1}$ (Roodman, 2009). As shown in Table 5, our regression model meets this condition as well.

After these explanations, despite the fact that the results from POLS and FE are also reported in Table 5, estimated coefficients of regression model given in Eq. (1) are interpreted based on SGMM estimates. While reporting t-statistics for SGMM estimates, the Windmeijer (2005) finite-sample correction is implemented. All of the independent variables are considered as endogenous except GDP growth in SGMM estimate. $\mathrm{ROA}_{\text {it-2 }}, \mathrm{Ln}(\text { sales })_{\mathrm{it}-2}$, FINRISK $_{\mathrm{it}-2}, \mathrm{CAPIN}_{\mathrm{it}-2}, \mathrm{BETA}_{\mathrm{it}-2}, \mathrm{NWC}_{\mathrm{it}-2}$, and R\&D $\mathrm{D}_{\mathrm{it}-2}$ are used as GMM-type instrumental variables in the transformed equation. Besides, $\Delta \mathrm{ROA}_{\mathrm{it}-1}, \Delta \operatorname{Ln}(\mathrm{sales})_{\mathrm{it}-1}, \Delta \mathrm{FINRISK}_{\mathrm{it}-1}$,

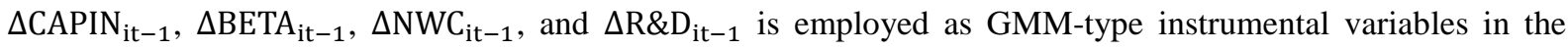
original equation.

As reported in Table 5, the estimated coefficient of $\mathrm{ROA}_{\mathrm{it}-1}$ is found to be positive and statistically significant, which implies that lagged profitability is an important determinant of current one. This finding for $\mathrm{ROA}_{\mathrm{it}-1}$ suggests significant and poorly persistent profits in the manufacturing industry in Turkey, which validates the dynamic nature of our model. We can also conclude that Turkish manufacturing industry is relatively competitive because of the low value of coefficient of one-year lagged ROA. Our finding for past profitability is consistent with the conclusions of prior studies about the profitability determinants in the literature (e.g. Pattitoni et al., 2014; Nunes \& Serrasqueiro, 2015; Vătavu, 2014; Cavaco et al., 2016; among others).

Firm size, as measured by $\mathrm{Ln}$ (sales), has a positive and significant impact on profitability of manufacturing firms. The positive effect of firm size implies that firm profitability increases with the increase of firm size. Microeconomic theory associates this result with impact of scale economies. This result reported in Table 5 is consistent with the findings of Martínez et al. (2007), Vintilă and Nenu (2015), Al-Jafari and Al Samman (2015), and Isik and Soykan (2013), but contradicts that of Goddard et al. (2005) and Shehata, Salhin, and El-Helaly, (2017).

As expected, financial risk (FINRISK) measured by the total debt-to-total assets ratio has a negative and statistically significant influence on profitability. A negative association between financial risk and profitability implies that there is a detrimental impact of debt structure on the profitability i.e. the negative effect of financial risk shows that a lower level of financial risk is likely to contribute to the increase in profitability. This finding is 
similar to those obtained from previous studies by Martínez et al. (2007), Schultz et al. (2010), Vintilă and Nenu (2015), Vătavu (2014), and Wu (2013), but different from those of Pratheepan (2014) and Shehata et al. (2017).

According to the result regarding capital intensity (CAPIN), we find a positive and statistically insignificant linkage between this variable and the profitability, meaning that firms with higher capital intensity perform worse. This finding paralleling the findings of Lee (2009) may reveal the importance of using assets effectively.

Contrary to what is expected, the estimated coefficient for market risk (BETA) is negative but not statistically significant, showing that the BETA has no significant influence on the profitability of firms operating in manufacturing sector. Wu (2013) find that the effect of BETA on ROA is positive and insignificant for Taiwan Stock Exchange, whereas Schultz et al. (2010) have reported a negative and insignificant link between BETA and ROA for Australian Stock Exchange.

The association between liquidity (NWC) and firm profitability is positive. It is statistically significant at the $10 \%$ level, indicating that higher liquidity measured by net working capital-to-total assets ratio leads to higher profitability. Our finding supports the findings of Şen and Oruç (2009), Pattitoni et al. (2014), and Al-Jafari and Al Samman (2015).

Contrary to our expectation, the coefficient estimate for research and development activities (R\&D) is negative and statistically significant at the $10 \%$ level of significance. This suggests that investing more on R\&D activities causes firms to have lower profitability. This result is in line with those of Wu (2013), Akben-Selcuk (2016), and Cavaco et al. (2016) but contradicts that of Nunes and Serrasqueiro (2015).

When we turn to the impact of economic growth (GDP), as expected, the profitability is positively and statistically influenced by economic growth, suggesting that an improvement in economic condition enhances manufacturing firm profits. Similar findings are founded in Pattitoni et al. (2014) for the EU-15 area.

Table 5. Estimation results

\begin{tabular}{|c|c|c|c|}
\hline \multirow[b]{2}{*}{ Independent variable } & \multicolumn{3}{|c|}{ Dependent variable: ROA } \\
\hline & POLS & FE & Two-step SGMM \\
\hline \multirow[t]{2}{*}{$\mathrm{ROA}_{\mathrm{it}-1}$} & $.4045^{* * *}$ & .0146 & $.1673^{* *}$ \\
\hline & (7.49) & $(.032)$ & $(2.33)$ \\
\hline \multirow[t]{2}{*}{ Ln(sales) } & $.0141^{* * *}$ & $.0195^{* *}$ & $.0279 * * *$ \\
\hline & $(6.47)$ & $(2.30)$ & $(4.33)$ \\
\hline \multirow[t]{2}{*}{ FINRISK } & $-.0702 * * *$ & $-.0679 *$ & $-.1200 * *$ \\
\hline & $(-4.06)$ & $(-1.87)$ & $(-2.81)$ \\
\hline \multirow[t]{2}{*}{ CAPIN } & .0002 & $.0009^{*}$ & .0004 \\
\hline & $(0.51)$ & $(1.90)$ & $(0.23)$ \\
\hline \multirow[t]{2}{*}{ BETA } & -.0103 & -.0011 & -.0087 \\
\hline & $(-1.21)$ & $(-0.08)$ & $(-0.43)$ \\
\hline \multirow[t]{2}{*}{ NWC } & $.0772 * * *$ & $.1496 * * *$ & $.0840 *$ \\
\hline & $(3.93)$ & $(4.89)$ & $(1.69)$ \\
\hline \multirow[t]{2}{*}{$R \& D$} & $-.0560^{* *}$ & .0392 & $-.1105^{*}$ \\
\hline & $(-2.12)$ & $(0.73)$ & $(-1.97)$ \\
\hline \multirow[t]{2}{*}{ GDP } & $.1940 * * *$ & $.1519^{* * *}$ & $.1561 * * *$ \\
\hline & $(4.15)$ & $(4.58)$ & $(3.10)$ \\
\hline \multirow[t]{2}{*}{ Constant } & $-.0361 * *$ & -.0723 & $-.0797 * *$ \\
\hline & $(-2.04)$ & $(1.38)$ & $(-2.10)$ \\
\hline \multicolumn{4}{|l|}{ Diagnostic tests } \\
\hline Firm fixed-effects & No & Yes & Yes \\
\hline R-squared & 0.4907 & 0.1585 & \\
\hline F-test & $50.29 * * *$ & $10.01^{* * *}$ & $18.08 * * *$ \\
\hline$J$-Statistic & & & 89.94 \\
\hline AR1 test & & & $-4.93 * * *$ \\
\hline AR2 test & & & 1.29 \\
\hline Number of instruments & & & 86 \\
\hline Observations & 809 & 809 & 809 \\
\hline Firms in sample & 120 & 120 & 120 \\
\hline
\end{tabular}

Note. Robust t-statistics for respective coefficients are in parentheses. $* * * \mathrm{p}<0.01, * * \mathrm{p}<0.05 \mathrm{ve} *<0.1$. 


\section{Conclusion}

Employing a balanced panel data on 120 Turkish listed manufacturing firms observed over a 8 - year period from 2005 to 2012, we empirically analyzes what determines the profitability of firms in manufacturing industry. Previous empirical studies on the association between profitability and its determinants are more likely to suffer from the problem of endogeneity. Because of this reason, we re-examine this association by employing a dynamic panel GMM specification.

The results of this empirical analysis indicate that firm profitability is positively and significantly related to past profitability, firm size in terms of total sales, net working capital, and GDP growth but inversely related to financial risk and R\&D investments. In addition to these findings, we do not find any significant impact of market risk and capital intensity on the profitability of Turkish manufacturing firms.

Our results are important for both firm management and government authorities. Firstly, firm executives should be more cautious about using the external funding and try to strike a balance between total liabilities and equity. Secondly, given today's competitive conditions, R\&D activities are of great importance for firms to grow and increase their profits. However, the results of this study demonstrate that the R\&D expenditures cause firm profitability to decrease. This suggests that firm managers should take various measures to control the costs arising from R\&D activities. Lastly, the government supports such as incentive and tax exception can encourage firms to focus more on $R \& D$ activities.

This study has some limitations. Firstly, the findings should be interpreted for the firms operating in manufacturing industry. They are not generalized for all publicly listed firms. Secondly, the ownership structures of firms are not taken into account. Lastly, similar to many other developing countries, a large majority of firms operating in Turkey are affiliated with business groups. In this study we do not control the effect of business group affiliation. This issue is beyond the scope of our study.

In this study, we only consider manufacturing firms, and in future studies, the factors that affect the profitability of firms operating in other sectors can be examined. The impact of the ownership structure of firms on the profitability as well as nonlinear connections between variables can also be included in the profitability analysis. Besides, the influence of last financial crisis on firm profitability can be analyzed.

\section{References}

Abbas, A., Bashir, Z., Manzoor, S., \& Akram, M. N. (2013). Determinants of firm's financial performance: An empirical study on textile sector of Pakistan. Business and Economic Research, 3(2), 76-86. https://doi.org/10.5296/ber.v3i2.3958

Akben-Selcuk, E. (2016). Factors Affecting Firm Competitiveness: Evidence from an Emerging Market. International Journal of Financial Studies, 4(9), 1-10. https://doi.org/10.3390/ijfs4020009

Al-Jafari, M. K., \& Al Samman, H. (2015). Determinants of Profitability: Evidence from Industrial Companies Listed on Muscat Securities Market. Review of European Studies, 7(11), 303. http://dx.doi.org/10.5539/res.v7n11p303

Arellano, M., \& Bond, S. (1991). Some tests of specification for panel data: Monte Carlo evidence and an application to employment equations. Review of Economic Studies, 58, 277-297. http://dx.doi.org/10.2307/2297968

Arellano, M., \& Bover, O. (1995). Another look at the instrumental variable estimation of error-components model. Journal of Econometrics, 68, 29-51. http://dx.doi.org/10.1016/0304-4076(94)01642-D

Baltagi, B. (2014). Econometric Analysis of Panel Data (5th ed.). Wiley, UK: Cornwall

Bayar, G., \& Tokpunar, S. (2014). Türkiye Imalat Sanayi Alt Sektörleri Üretiminin Belirleyicileri-Panel Veri Analizi/Determinants of Turkish Manufacturing Industry Production in Sub-Sectors: A Panel Data Analysis. Business and Economics Research Journal, 5(1), 67-85.

Blundell, R., \& Bond, S. (1998) Initial conditions and moment restrictions in dynamic panel data models. Journal of Econometrics, 87(1), 115-143. https://doi.org/10.1016/S0304-4076(98)00009-8

Bond, S. R. (2002). Dynamic panel data models: A guide to micro data methods and practice. Portuguese economic journal, 1(2), 141-162. https://doi.org/10.1007/s10258-002-0009-9

Çakir, H. M., \& Küçükkaplan, İ. (2012). İsletme Sermayesi Unsurlarının Firma Degeri ve Karlılıgı Üzerindeki Etkisinin İMKB'de İslem Gören Üretim Firmalarında 2000-2009 Dönemi İçin Analizi. Muhasebe ve Finansman Dergisi, 53, 69-85. 
Cavaco, S., Challe, E., Crifo, P., Rebérioux, A., \& Roudaut, G. (2016). Board independence and operating performance: analysis on (French) company and individual data. Applied Economics, 48(52), 5093-5105. https://doi.org/10.1080/00036846.2016.1170936

Doğan, M., \& Topal, Y. (2016). Karlılığı Belirleyen Finansal Faktörler: BIST’te İşlem Gören İmalat Sanayi Firmaları Üzerine Bir Araştırma. Optimum Ekonomi ve Yönetim Bilimleri Dergisi, 3(1), 55-66.

Goddard, J., Tavakoli, M., \& Wilson, J. O. S. (2005). Determinants of profitability in European manufacturing and services: Evidence from dynamic panel model. Applied Financial Economics, 15(18), 1269-1282. https://doi.org/10.1080/09603100500387139

Greene,W. H. (2003), Econometric Analysis (5th ed.). Singapore: Pearson Education Inc.

Greiner, L. (1972). Evolutions and revolutions as organizations grow. Harvard Business Review, 50(4), 37-46.

Hatem, B. S. (2014). Determinants of firm performance: A comparison of European countries. International Journal of Economics and Finance, 6(10), 243-249. https://doi.org/10.5539/ijef.v6n10p243

Işık, N., Engeloğlu, Ö., \& Kılınç, E. C. (2016). Araştirma ve Geliştirme Harcamalarinin, Kârlilik Ve Satişlar Üzerindeki Etkisi: Borsa Istanbul Firmalari Üzerine Bir Uygulama. Erciyes Üniversitesi İktisadi ve İdari Bilimler Fakültesi Dergisi, (47), 27-46.

Isik, O., \& Soykan, M. E. (2013). Large shareholders and firm performance: Evidence from Turkey. European Scientific Journal, 9(25), 23-37.

Kafouros, M. I. (2005). R\&D and productivity growth: Evidence from the UK. Economics of Innovation and New Technology, 14(6), 479-497. https://doi.org/10.1080/1043859042000269098

Kocaman, M., Altemur, N., Aldemir, S., \& Karaca, S. S. (2016) Ekonomik Karliliği Etkileyen Faktörler: İSO 500 Sanayi İşletmeleri Uygulamasi. Mustafa Kemal Üniversitesi Sosyal Bilimler Enstitüsü Dergisi/Mustafa Kemal University Journal of Social Sciences Institute, 13(35), 320-332.

Korkmaz, Ö., \& Karaca, S. S. (2014). Üretim Isletmelerinde Firma Karliliginin Finansal Belirleyicileri ve BIST Imalat Sanayi Uygulamasi/Financial Determinants of Firm Profitability in Manufacturing Firms and An Application on BIST Manifacturing Firms. Ege Akademik Bakis, 14(1), 21-29. https://doi.org/10.21121/eab.2014118064

Lee, J. (2009). Does Size Matter in Firm Performance? Evidence from US Public Firms. International Journal of the Economics of Business, 16(2), 189-203. http://dx.doi.org/10.1080/13571510902917400

Margaretha, F., \& Supartika, N. (2015). Factors Affecting Profitability of Small Medium Enterprises (SMEs) Firm Listed in Indonesia Stock Exchange. Journal of Economics, Business and Management, 4(2), 132-137. https://doi.org/10.7763/JOEBM.2016.V4.379

Martínez, J. I., Stöhr, B. S., \& Quiroga, B. F. (2007). Family ownership and firm performance: Evidence from public companies in Chile. Family Business Review, 20(2), 83-94. http://dx.doi.org/10.1111/j.1741-6248.2007.00087.x

Menicucci, E., \& Paolucci, G. (2016). The determinants of bank profitability: Empirical evidence from European banking sector. Journal of Financial Reporting and Accounting, 14(1), 86-115. http://dx.doi.org/10.1108/JFRA-05-2015-0060

Miralles-Marcelo, J. L., Del Mar Miralles-Quirós, M., \& Lisboa, I. (2014). The impact of family control on firm performance: Evidence from Portugal and Spain. Journal of Family Business Strategy, 5(2), 156-168. http://dx.doi.org/10.1016/j.jfbs.2014.03.002

Mueller, D. C. (1977). The persistence of profits above the norm. Economica, 44(176), 369-380. https://doi.org/10.2307/2553570

Mueller, D. C. (1986). Profits in The Long Run. Cambridge: Cambridge University Press. https://doi.org/10.1017/CBO9780511664731

Myers, S. C., \& Rajan, R. G. (1998). The paradox of liquidity. The Quarterly Journal of Economics, 113(3), 733-771. https://doi.org/10.1162/003355398555739.

Nickell, S. (1981). Biases in Dynamic Models with Fixed Effects'. Econometrica, 49, 1417-1426. https://doi.org/10.2307/1911408

Niresh, J. A., \& Velnampy, T. (2014). Firm Size and Profitability: A Study of Listed Manufacturing Firms in Sri Lanka. International Journal of Business and Management, 9(4), 57-64. 
http://dx.doi.org/10.5539/ijbm.v9n4p57

Nunes, P. M., \& Serrasqueiro, Z. (2015). Profitability determinants of Portuguese knowledge-intensive business services: Empirical evidence using panel data models. Applied Economics Letters, 22(1), 51-56. https://doi.org/10.1080/13504851.2014.925041

Pattitoni, P., Petracci, B., \& Spisni, M. (2014). Determinants of profitability in the EU-15 area. Applied Financial Economics, 24(11), 763-775. http://dx.doi.org/10.1080/09603107.2014.904488

Pervan, M., \& Mlikota, M. (2013). What determines the Profitability of Companies: Case of Croatian food and beverage industry. Economic Research-Ekonomska Istraživanja, 26(1), 277-286. https://doi.org/10.1080/1331677X.2013.11517602

Poutziouris, P., Savva, C. S., \& Hadjielias, E. (2015). Family involvement and firm performance: Evidence from UK listed firms. Journal of Family Business Strategy, 6(1), 14-32. http://dx.doi.org/10.1016/j.jfbs.2014.12.001

Pratheepan, T. (2014). A Panel Data Analysis of Profitability Determinants: Empirical Results from Sri Lankan Manufacturing Companies. International Journal of Economics, Commerce and Management, 2(12), 1-9.

Roodman, D. (2009). How to Do Xtabond2: An Introduction to Difference and System GMM in Stata. The Stata Journal, 9, 86-136.

Schultz, E. L., Tan, D. T., \& Walsh, K. D. (2010). Endogeneity and the corporate governance-performance relation. Australian journal of Management, 35(2), 145-163. https://doi.org/10.1177/0312896210370079

Şen, M., \& Ed, O. (2009). Relationship between efficiency level of working capital management and return on total assets in ISE (Istanbul Stock Exchange). International Journal of Business and Management, 4(10), 109-114.

Shehata, N., Salhin, A., \& El-Helaly, M. (2017). Board diversity and firm performance: Evidence from the U.K. SMEs. Applied Economics, 1-16. http://dx.doi.org/10.1080/00036846.2017.1293796

Sivathaasan, N., Tharanika, R., Sinthuja, M., \& Hanitha, V. (2013). Factors determining profitability: A study of selected manufacturing companies listed on Colombo Stock Exchange in Sri Lanka. European Journal of Business and Management, 5(27), 99-107.

Vătavu, S. (2014). The determinants of profitability in companies listed on the Bucharest stock exchange. Annals of the University of Petrosani, Economics, 14(1), 329-338.

Vintila, G., \& Nenu, E. A. (2015). An Analysis of Determinants of Corporate Financial Performance: Evidence from the Bucharest Stock Exchange Listed Companies. International Journal of Economics and Financial Issues, 5(3), 732-739.

Voulgaris, F., \& Lemonakis, C. (2014). Competitiveness and profitability: The case of chemicals, pharmaceuticals and plastics. The Journal of Economic Asymmetries, 11, 46-57. https://doi.org/10.1016/j.jeca.2014.04.003

Windmeijer, F. (2005) A finite sample correction for the variance of linear efficient two-step GMM estimators. Journal of Econometrics, 126(1), 25-51. https://doi.org/10.1016/j.jeconom.2004.02.005

Wintoki, M. B., Linck, J. S., \& Netter, J. M. (2012). Endogeneity and the dynamics of internal corporate governance. Journal of Financial Economics, 105(3), 581-606. http://dx.doi.org/10.1016/j.jfineco.2012.03.005

Wu, C. H. (2013). Family ties, board compensation and firm performance. Journal of Multinational Financial Management, 23(4), 255-271. http://dx.doi.org/10.1016/j.mulfin.2013.01.001

Zhou, H., He, F., \& Wang, Y. (2017). Did family firms perform better during the financial crisis? Newinsights fromthe S\&P 500 firms. Global Finance Journal. http://dx.doi.org/10.1016/j.gfj.2017.01.001

\section{Copyrights}

Copyright for this article is retained by the author(s), with first publication rights granted to the journal.

This is an open-access article distributed under the terms and conditions of the Creative Commons Attribution license (http://creativecommons.org/licenses/by/4.0/). 